\title{
Protocol
}

\section{Labeling Nuclear DNA Using DAPI}

\author{
Brad Chazotte
}

\section{INTRODUCTION}

A number of fluorescent stains are available that label DNA and allow easy visualization of the nucleus in interphase cells and chromosomes in mitotic cells, including Hoechst, 4',6-diamidino2-phenylindole (DAPI), ethidium bromide, propidium iodide, and acridine orange. Although not as bright as the vital Hoechst stains for DNA, DAPI has greater photostability. It is believed that DAPI associates with the minor groove of double-stranded DNA, with a preference for the adenine-thymine clusters. Cells must be permeabilized and/or fixed for DAPI to enter the cell and to bind DNA. Fluorescence increases approximately 20-fold when DAPI is bound to double-stranded DNA. This protocol describes the use of DAPI to label nuclear DNA of cells grown in culture.

\section{RELATED INFORMATION}

Autofluorescence from endogenous cellular molecules such as the reduced forms of nicotinamide adenine dinucleotide or flavin adenine dinucleotide can interfere with imaging by reducing the signal-to-noise ratio. This occurs when the excitation and/or emission wavelengths of the probe and the autofluorescing molecules are similar, e.g., frequently with excitation wavelengths $<500 \mathrm{~nm}$, and particularly at ultraviolet wavelengths. Autofluorescence can be reduced by careful selection of the excitation and the emission wavelengths used, by treating fixed cells with reducing agents (e.g., a $1 \%$ solution of sodium borohydride $\left[\mathrm{NaBH}_{4}\right]$ for $20 \mathrm{~min}$ ), and by comparing the experimental images with unlabeled control slides. Avoid fixation with glutaraldehyde, because it can increase interference from cellular autofluorescence, most frequently at wavelengths $<500 \mathrm{~nm}$.

This protocol assumes that the cells of interest were grown on glass microscope coverslips immersed in small Petri dishes containing culture medium. Generally, labeling conditions vary by cell type, and it might be necessary to alter the protocol for a particular use. To mount cells labeled using the technique described here, see Mounting Live Cells onto Microscope Slides (Chazotte 2011).

\section{MATERIALS}

CAUTIONS AND RECIPES: Please see the end of this protocol for appropriate handling of materials marked with $<!>$, and recipes for reagents marked with $<\mathbf{R}>$.

\section{Reagents}

Cells of interest, grown on coverslips

$<$ !>DAPI (10 mg/mL in $\mathrm{H}_{2} \mathrm{O}$ stock solution; Invitrogen D1306)

Store stock solution at $4{ }^{\circ} \mathrm{C}$, protected from light. The lactate salt of DAPI is more $\mathrm{H}_{2} \mathrm{O}$-soluble than the chloride salt, but DAPI is not very soluble in PBS; therefore, use $\mathrm{H}_{2} \mathrm{O}$ to prepare the stock solution.

$<$ ! $>$ Formaldehyde (3.7\%), freshly prepared

$<$ R $>$ Phosphate-buffered saline (PBS)

Adapted from Imaging: A Laboratory Manual (ed. Yuste). CSHL Press,

Cold Spring Harbor, NY, USA, 2010.

Cite as: Cold Spring Harb Protoc; 2011; doi:10.1101/pdb.prot5556

www.cshprotocols.org 
Prepare PBS with added $\mathrm{CaCl}$ and $\mathrm{MgCl}_{2}\left(\mathrm{PBS}^{+}\right)$. This solution allows cells to adhere to each other and to the substrate. If cells are in medium containing no $\mathrm{Ca}^{2+}$ or $\mathrm{Mg}^{++}$, they will round up and detach from the substrate.

$<$ ! $>$ Triton X-100 (0.2\%)

\section{Equipment}

Cell culture dishes, sterile

Microscope, fluorescence, equipped with an ultraviolet (UV) filter set

$<!>$ For confocal microscopy laser excitation, use a UV laser or, if sufficiently intense, the UV line of an argon-ion laser.

\section{METHOD}

Cells that have been immunolabeled can be stained with DAPI by starting at Step 7.

1. Dilute the DAPI stock solution 1:5000 in $\mathrm{PBS}^{+}$.

2. Aspirate the cell medium from cells grown on coverslips. Rinse the cells three times with $\mathrm{PBS}^{+}$. Do not allow the cells to dry out at any time during the protocol.

3. Fix the cells for $10 \mathrm{~min}$ in $3.7 \%$ formaldehyde.

4. Aspirate the fixative. Rinse the cells three times, 5 min each, in $\mathrm{PBS}^{+}$.

5. Permeabilize the cells by immersion in $0.2 \%$ Triton $X-100$ for 5 min.

6. Aspirate the Triton. Rinse the cells three times, 5 min each, in $\mathrm{PBS}^{+}$.

7. Incubate the cells for 1-5 min at room temperature in DAPI labeling solution (from Step 1).

8. Aspirate the labeling solution. Rinse the cells three times in $\mathrm{PBS}^{+}$.

9. Mount the coverslips as described in Mounting Live Cells onto Microscope Slides (Chazotte 2011).

10. Image the cells $\left(\lambda_{\text {ex }} \sim 359 \mathrm{~nm}, \lambda_{\text {em }} \sim 461 \mathrm{~nm}\right.$ when DAPI is bound to DNA).

\section{ACKNOWLEDGMENTS}

I thank my wife, Nancy, and my daughter, Bryanna, for their patience while I was writing this article. I dedicate this article in memory of my mother, Cozette Chazotte, 1919-2009.

\section{REFERENCES}

Chazotte B. 2011. Mounting live cells onto microscope slides. Cold Spring Harb Protoc doi: 10.1101/pdb.prot5554.

\section{RECIPES}

[NOTE: Recipes for reagents marked with the $<\mathbf{R}>$ symbol not listed below can be found online at http://www. cshprotocols.org/recipes.]

\section{Phosphate-buffered saline (PBS)}

\begin{tabular}{lllll}
\hline Reagent & $\begin{array}{l}\text { Amount to add } \\
\text { (for 1X solution) }\end{array}$ & $\begin{array}{l}\text { Final concentration } \\
(1 \mathrm{X})\end{array}$ & $\begin{array}{l}\text { Amount to add } \\
\text { (for 10X stock) }\end{array}$ & $\begin{array}{l}\text { Final concentration } \\
(10 X)\end{array}$ \\
\hline $\mathrm{NaCl}$ & $8 \mathrm{~g}$ & $137 \mathrm{mM}$ & $80 \mathrm{~g}$ & $1.37 \mathrm{M}$ \\
$<!>\mathrm{KCl}$ & $0.2 \mathrm{~g}$ & $2.7 \mathrm{mM}$ & $2 \mathrm{~g}$ & $27 \mathrm{mM}$ \\
$\mathrm{Na}_{2} \mathrm{HPO}_{4}$ & $1.44 \mathrm{~g}$ & $10 \mathrm{mM}$ & $14.4 \mathrm{~g}$ & $100 \mathrm{mM}$ \\
$\mathrm{KH}_{2} \mathrm{PO}_{4}$ & $0.24 \mathrm{~g}$ & $1.8 \mathrm{mM}$ & $2.4 \mathrm{~g}$ & $18 \mathrm{mM}$
\end{tabular}


If necessary, PBS may be supplemented with the following:

$\begin{array}{lllll}<!>\mathrm{CaCl}_{2} \cdot 2 \mathrm{H}_{2} \mathrm{O} & 0.133 \mathrm{~g} & 1 \mathrm{mM} & 1.33 \mathrm{~g} & 10 \mathrm{mM} \\ <!>\mathrm{MgCl}_{2} \cdot 6 \mathrm{H}_{2} \mathrm{O} & 0.10 \mathrm{~g} & 0.5 \mathrm{mM} & 1.0 \mathrm{~g} & 5 \mathrm{mM}\end{array}$

$<$ !> PBS can be made as a $1 \mathrm{X}$ solution or as a $10 \mathrm{X}$ stock. To prepare $1 \mathrm{~L}$ of either $1 \mathrm{X}$ or $10 \mathrm{X}$ PBS, dissolve the reagents listed above in $800 \mathrm{~mL}$ of $\mathrm{H}_{2} \mathrm{O}$. Adjust the $\mathrm{pH}$ to 7.4 (or 7.2, if required) with $\mathrm{HCl}$, and then add $\mathrm{H}_{2} \mathrm{O}$ to $1 \mathrm{~L}$. Dispense the solution into aliquots and sterilize them by autoclaving for $20 \mathrm{~min}$ at $15 \mathrm{psi}\left(1.05 \mathrm{~kg} / \mathrm{cm}^{2}\right)$ on liquid cycle or by filter sterilization. Store PBS at room temperature.

\section{CAUTIONS}

[NOTE: For reagents marked with the <!> symbol not listed below, please consult the manufacturer's Material Safety Data Sheet for further information.]

$\mathrm{CaCl}_{2}$ (Calcium chloride) is hygroscopic and may cause cardiac disturbances. It may be harmful by inhalation, ingestion, or skin absorption. Do not breathe the dust. Wear appropriate gloves and safety goggles.

DAPI (4',6-Diamidine-2'-phenylindole dihydrochloride) is a possible carcinogen. It may be harmful by inhalation, ingestion, or skin absorption. It may also cause irritation. Avoid breathing the dust and vapors. Wear appropriate gloves and safety glasses and use in a chemical fume hood.

Formaldehyde ( $\mathrm{HCOH})$ is highly toxic and volatile. It is also a carcinogen. It is readily absorbed through the skin and is irritating or destructive to the skin, eyes, mucous membranes, and upper respiratory tract. Avoid breathing the vapors. Wear appropriate gloves and safety glasses. Always use in a chemical fume hood. Keep away from heat, sparks, and open flame.

$\mathrm{HCl}$ (Hydrochloric acid, Hydrochloride) is volatile and may be fatal if inhaled, ingested, or absorbed through the skin. It is extremely destructive to mucous membranes, upper respiratory tract, eyes, and skin. Wear appropriate gloves and safety glasses. Use with great care in a chemical fume hood. Wear goggles when handling large quantities.

$\mathrm{KCl}$ (Potassium chloride) may be harmful by inhalation, ingestion, or skin absorption. Wear appropriate gloves and safety glasses.

$\mathrm{MgCl}_{2}$ (Magnesium chloride) may be harmful by inhalation, ingestion, or skin absorption. Wear appropriate gloves and safety glasses and use in a chemical fume hood.

Triton X-100 causes severe eye irritation and burns. It may be harmful by inhalation, ingestion, or skin absorption. Wear appropriate gloves and safety goggles.

UV light and/or UV radiation is dangerous and can damage the retina of the eyes. Never look at an unshielded UV light source with naked eyes. Examples of UV light sources that are common in the laboratory include handheld lamps and transilluminators. View only through a filter or safety glasses that absorb harmful wavelengths. UV radiation is also mutagenic and carcinogenic. To minimize exposure, make sure that the UV light source is adequately shielded. Wear protective appropriate gloves when holding materials under the UV light source. 